\title{
EFFECT OF SOME ANTIHYPERTENSIVE DRUGS ON ALKALINE PHOSPHATASE AND DNA OF MICE
}

\section{EL-KHAWAGA 0.Y.1* ${ }^{*}$ EL-WASEEF A. ${ }^{1}$, ELLAZEC Y.0. ${ }^{2}$, EL-NAGGAR M.M. ${ }^{1}$ AND ABD ALLA M.1}

${ }^{1}$ Chemistry Department, Faculty of Science, Mansoura University, Mansoura, Egypt. 2Botany Department, Faculty of Science, Mansoura University, Mansoura, Egypt. ${ }^{*}$ Corresponding Author: Email-dr_elkhawaga@yahoo.com

\author{
Received: March 13, 2013; Accepted: March 28, 2013
}

\begin{abstract}
Various antihypertensive drugs are in a wide use for the treatment of hypertension. It is important to investigate the influences of chronic administration of these drugs on genomic DNA. So the objective of the present study was to elucidate the effects of chronic administration of some antihypertensive drugs e.g. amlodipine, atenolol and captopril on alkaline phosphatase(ALP) and genomic DNA in liver, spleen and kidney of Swiss albino mice. A total of 150 Swiss albino mice were divided into 10 groups (15 mice each): a control group and 3 groups to be treated by various doses of each of the three drugs. ALP was assayed in liver, spleen and kidney after drugs administration for 1 ; 3 and 6 months. The genotoxic effects of the three antihypertensive drugs were evaluated by RAPD-PCR technique. All studied drugs caused elevations in the activities of ALP in liver, spleen and kidney homogenates. Amlodipine induced DNA damage in the homogenates of liver, spleen and kidney. On the other hand, atenolol and captopril did not affect the genomic DNA. From our findings we can conclude that the chronic administration of the above antihypertensive drugs induce inflammation and amlodipine had toxic effect on the genomic DNA while atenolol and captopril had no apparent effects on DNA.
\end{abstract}

Keywords- Antihypertensive, DNA damage, alkaline phosphatase, RAPD-PCR- atenolol, captopril, amlodipine

Citation: El-Khawaga O.Y., et al. (2013) Effect of Some Antihypertensive Drugs on Alkaline Phosphatase and DNA of Mice. International Journal of Genomics and Proteomics, ISSN: 0976-4887 \& E-ISSN: 0976-4895, Volume 4, Issue 1, pp.-60-63.

Copyright: Copyright@2013 El-Khawaga O.Y., et al. This is an open-access article distributed under the terms of the Creative Commons Attribution License, which permits unrestricted use, distribution and reproduction in any medium, provided the original author and source are credited.

\section{Introduction}

Cardiovascular diseases are one of the leading causes of death for people in developed countries world-wide. Hypertension and osteoporosis are frequent diseases among elders. Both are induced by interaction of many genetic and environmental factors [1]. Many metabolic and physiological changes occur in hypertensive individuals and some of these processes stem from the associated increased oxidative stress [2]. The depression in antioxidant enzymes and increase in oxidants in the hypertensive state have been reported to increase the production of reactive oxygen species [3,4]. The reactive oxygen species/free radicals resulting from the oxidantantioxidant imbalance tend to accumulate and are known to cause oxidative damage to the cellular macromolecules including the genetic material [5]. The genetic instability can include mutations, chromosomal aberrations and unscheduled DNA synthesis [6,7]. Amlodipine is a derivative of dihydropyridine and is one of calcium channel blockers. Its principal action is to inhibit calcium entry through voltage-gated transmembrane L-type channels, thus decreasing intercellular calcium concentration and inducing smooth muscle relaxation [8-10]. Atenolol is a beta 1-selective drug that binds to the beta-receptors and prevents the stimulation by catecholamine resulting in lowering of heart rate and of the systemic blood pressure [11]. Captopril is an angiotensin-converting enzyme (ACE) inhibitor used for the treatment of hypertension and some types of congestive heart failure. Captopril was the first ACE inhibitor developed and was considered a break through both because of its novel mechanism of action and also because of the revolutionary development process [12].

Alkaline phosphatase (ALP) is an enzyme that catalyzes the hydrolysis of organic pyrophosphate and inhibitor of vascular calcification [13]. Although ALP is expressed in a variety of tissues, its concentrations are highest in bone, liver and kidney [14]. Accordingly, serum levels of ALP are used in clinical practice as a marker of hepatic, peripheral vascular and bony diseases [15]. No published data have been found in the relevant literature on the toxicity of antihypertensive drugs on the DNA of normal mice and thereby the present study was undertaken to determine the effect of chronic administration of recommended ; half recommended and one and half recommended doses of the antihypertensive drugs amlodipine, atenolol and captopril on the genomic DNA and on the activity of alkaline phosphatase (ALP) in the liver, spleen and kidney of Swiss albino mice.

\section{Materials and Methods \\ Chemicals}

Atenolol was purchased from Kahira Pharmaceutical. and Chemical Industries Company (Egypt). Amlodipine was purchased from Pfizer (Egypt) and captopril was purchased from Bristol Myers Squibb 
(Egypt). All other chemicals were of analytical grade.

\section{Experimental Animals}

All experiments were performed using adult female Swiss albino mice, with an average body weight of $25 \mathrm{~g}$ purchased from Theodore Bilharz Research Institute, Giza, Egypt. The mice were housed in steel mech cage and provided with commercial standard diet and tap water ad libitum.

A total of 150 Swiss albino mice were divided into 10 groups, 15 mice each, according to the following scheme: group 1, control (untreated) mice; groups 2-4, mice received captopril in doses of $1.3 \mathrm{mg} / \mathrm{kg}$ b.w. (low dose; half the recommended dose), $2.6 \mathrm{mg} / \mathrm{kg}$ b.w. (the recommended dose) and $3.9 \mathrm{mg} / \mathrm{kg}$ b.w. (high dose; one and half times the recommended dose) respectively every other day; groups 5-7, mice received amlodipine in doses of $0.26 \mathrm{mg} / \mathrm{kg}$ b.w. (low dose; half the recommended dose), $0.52 \mathrm{mg} / \mathrm{kg}$ b.w. (the recommended dose) and $0.78 \mathrm{mg} / \mathrm{kg}$ b.w. (high dose; one and half times the recommended dose) respectively every other day and groups 8-10, mice received atenolol in doses of $5.2 \mathrm{mg} / \mathrm{kg} \mathrm{b.w.} \mathrm{(low}$ dose; half the recommended dose), $10.4 \mathrm{mg} / \mathrm{kg} \mathrm{b.w}$. (the recommended dose) and $15.6 \mathrm{mg} / \mathrm{kg} \mathrm{b.w.} \mathrm{(high} \mathrm{dose;} \mathrm{one} \mathrm{and} \mathrm{half} \mathrm{times}$ the recommended dose) respectively every other day. Each of the nine groups of mice receiving the drugs were classified into subgroups, 5 animals each. The animals of the subgroups were sacrificed at 1, 3, 6 months of starting administration of the drugs while the animals of the control group were all killed at the end of the experimental period. Liver, spleen and kidney were immediately excised, washed in ice-cold saline, blotted dry and weighed for measuring various biochemical parameters.

\section{Preparation of Homogenates}

An accurately weighed piece of each of liver, spleen and kidney tissues was homogenized in ice-cold $0.9 \%$ saline using a Teflon pestle connected to a homogenizer motor. The homogenates were adjusted at a concentration of $5 \%(w / v)$. The homogenates were centrifuged at $5000 \mathrm{rpm}$ for 30 minutes at $4^{\circ} \mathrm{C}$ to remove cell debris and nuclei. The resulting supernatant was used for biochemical analysis.

\section{Biochemical Analysis}

Alkaline phosphatase activity was estimated by the method of Ali et al. [16] using a commercial available assay kit (AAT Bioquest $₫$, Inc., Egypt). Protein in the homogenates was determined by the method of Lowry et al [17].

\section{Genomic DNA Extraction and RAPD-PCR Analysis}

Total DNA from mice tissues was extracted and purified according to the Wizard ( Genomic DNA Purification Kit supplied by Promega Corporation (USA). Among several primers used for screening and RAPD-PCR analyses of the studied samples only one primer OPE13: 5-CCCGATTCGG-3- was chosen. Genomic DNA was analyzed with random amplified polymorphic DNA polymerase chain reaction (RAPD-PCR) technique according to the method described by Williams et al [18]. The PCR amplifications were performed in $25 \mu$ of the reaction mixture containing $1 \mu$ l of template DNA, $3.5 \mu$ primer and pure taq Ready- To- Go PCR beads. The PCR conditions were as follows: denaturing at $94^{\circ} \mathrm{C}$ for $1.5 \mathrm{~min}$, annealing at $37^{\circ} \mathrm{C}$ for 1.5 min and extension at $72^{\circ} \mathrm{C}$ for $3 \mathrm{~min}$. The products were mixed with the loading buffer and were loaded in $2 \%$ agarose gels and electrophoresed at $100 \mathrm{~V}$ for $1 \mathrm{~h}$. The gels were stained with ethidium bromide and visualized under UV light.

\section{Statistical analysis}

The results are expressed as means \pm SD. Statistical analysis was performed according to the method of Murray [19]. Data were analyzed using unpaired Student,s t-test. $P$ values of $<0.05$ were considered to be statistically significant.

Table 1- Alkaline phosphatase in liver (L), spleen (S) and kidney (K) of control mice and mice treated with various doses of Captopril, Atenolol and Amlodipine.

\begin{tabular}{|c|c|c|c|c|c|c|c|c|c|}
\hline \multirow{3}{*}{ Groups } & \multicolumn{9}{|c|}{ Alkaline Phosphatase (IU) } \\
\hline & \multicolumn{3}{|c|}{$1 \mathrm{~m}$} & \multicolumn{3}{|c|}{$3 \mathrm{~m}$} & \multicolumn{3}{|c|}{$6 \mathrm{~m}$} \\
\hline & L & S & K & L & S & K & L & S & K \\
\hline \multicolumn{10}{|l|}{ Group 1} \\
\hline (Control) & $14.7 \pm 1.81$ & $3.88 \pm 0.70$ & $3.36 \pm 0.947$ & $14.7 \pm 1.81$ & $3.88 \pm 0.70$ & $3.36 \pm 0.947$ & $14.7 \pm 1.81$ & $3.88 \pm 0.70$ & $3.36 \pm 0.947$ \\
\hline Group 2 & $18.6 \pm 0.55$ & $11.59 \pm 2.3$ & $16.08 \pm 0.55$ & $17.13 \pm 2.82$ & $11.88 \pm 0.11$ & $11.55 \pm 1.06$ & $54.93 \pm 3.98$ & $8.6 \pm 1.22$ & $12.52 \pm 1.18$ \\
\hline (Treated with Captopril 1.3mg/kg) & ** & ** & ** & ** & ** & ** & ** & ** & ** \\
\hline $\begin{array}{l}\text { Group } 3 \\
\text { (Treated with Captopril } 2.6 \mathrm{mg} / \mathrm{kg} \text { ) }\end{array}$ & $\underset{* *}{25.14 \pm 0.75}$ & $\underset{* *}{15.96 \pm 0.54}$ & $\underset{* *}{15.5 \pm 1.98}$ & $\underset{* *}{32.32} \pm 4.009$ & $\underset{* *}{16.9 \pm 1.34}$ & $\underset{* *}{19.29 \pm 1.4}$ & $\underset{* *}{26.24 \pm 1.046}$ & $\underset{* *}{19.33 \pm 1.27}$ & $16.14 \pm 1.605$ \\
\hline Group 4 & $34.99 \pm 1.65$ & $31.39 \pm 1.5$ & $10.98 \pm 0.92$ & $61.55 \pm 3.45$ & $35.19 \pm 2.21$ & $16.76 \pm 0.72$ & $26.76 \pm 1.18$ & $6.4 \pm 1.83$ & $5.47 \pm 1.025$ \\
\hline (Treated with Captopril $3.9 \mathrm{mg} / \mathrm{kg}$ ) & $* *$ & ** & $* *$ & ** & ** & ** & $* \star$ & ** & ** \\
\hline Group 5 & $20.83 \pm 0.48$ & $8.84 \pm 0.86$ & $1.08 \pm 0.176$ & $43.9 \pm 0.346$ & $7.09 \pm 0.72$ & $3.98 \pm 0.339$ & $17.58 \pm 1.06$ & $8.80 \pm 0.78$ & $3.17 \pm 0.784$ \\
\hline (Treated with Atenolol & ** & ** & * & ** & ** & NS & ** & ** & NS \\
\hline Group 6 & $25.34 \pm 1.83$ & $12.66 \pm 1.4$ & $18.57 \pm 1.59$ & $70.76 \pm 1.89$ & $5.93 \pm 0.28$ & $14.414 \pm 1.166$ & $18.74 \pm 0.40$ & $26.45 \pm 0.905$ & $1.86 \pm 0.21$ \\
\hline (Treated with Atenolol 10.4mg/kg) & ** & ** & ** & ** & * & ** & ** & ** & $\star *$ \\
\hline Group 7 & $29.81 \pm 0.94$ & $14 . .08 \pm 1.59$ & $12.51 \pm 1.27$ & $53.37 \pm 1.26$ & $9.916 \pm 1.011$ & $13.62 \pm 0.33$ & $24.014 \pm 0.59$ & $30.5 \pm 0.558$ & $1.93 \pm 006$ \\
\hline (Treated with Atenolol $15.6 \mathrm{mg} / \mathrm{kg}$ ) & ** & ** & ** & ** & ** & ** & ** & ** & ** \\
\hline Group 8 & $61.2 \pm 0.593$ & $10.25 \pm 0.41$ & $10.0 \pm 4.02$ & $51.9 \pm 3.04$ & $5.314 \pm 0.021$ & $18.5 \pm 0.39$ & $19.6 \pm 1.73$ & $10.97 \pm 0.813$ & $23.05 \pm 0.629$ \\
\hline (Treated with Amlodipine $0.26 \mathrm{mg} / \mathrm{kg}$ ) & ** & ** & ** & ** & ** & ** & ** & ** & ** \\
\hline Group 9 & $9.23 \pm 0.72$ & $25.3 \pm 0.014$ & $6.23 \pm 1.407$ & $16.6 \pm 0.84$ & $6.48 \pm 0.148$ & $7.96 \pm 1.42$ & $17.69 \pm 1.54$ & $6.39 \pm 0.417$ & $16.6 \pm 1.32$ \\
\hline (Treated with Amlodipine $0.52 \mathrm{mg} / \mathrm{kg}$ ) & ** & ** & ** & ** & ** & ** & $* \star$ & $* *$ & ** \\
\hline Group 10 & $19.97 \pm 8.06$ & $9.48 \pm 0.49$ & $9.22 \pm 2.33$ & $18.6 \pm 0.134$ & $9.89 \pm 1.25$ & $9.54 \pm 2.13$ & $21.2 \pm 0.226$ & $19.7 \pm 0.74$ & $5.08 \pm 0.95$ \\
\hline (Treated with Amlodipine $0.78 \mathrm{mg} / \mathrm{kg}$ ) & ** & ** & ** & ** & ** & ** & ** & ** & ** \\
\hline
\end{tabular}

**highly significant compared to the corresponding control level.

$1 \mathrm{~m}, 3 \mathrm{~m}$ and $6 \mathrm{~m}$ : samples after treatment for 1,3 and 6 months respectively. 


\section{Results}

[Table-1] illustrates the alkaline phosphatase (ALP) activities in mice of different groups. After administration of captopril for one, three and six months in doses of 1.3, 2.6, $3.6 \mathrm{mg} / \mathrm{kg} \mathrm{b.w.,} \mathrm{highly}$ significant elevations in the activities of ALP in the liver, spleen and kidney homogenates were found compared to its activities in the homogenates of the control group.

Similarly, a highly significant increases in the activities of ALP in the liver and spleen homogenates of mice were observed after administration of $5.2,10.4,15.6 \mathrm{mg} / \mathrm{kg}$ b.w. atenolol for one, three and six months. On the other hand, a significant decrease was observed in ALP activity in the kidney homogenates after administration of 5.2 $\mathrm{mg} / \mathrm{kg}$ b.w. atenolol for one month while no significant changes were found after three and six months from the administration of atenolol. Moreover, a significant decrease in the kidney ALP activity on the administration of 10.4 and $15.6 \mathrm{mg} / \mathrm{kg} \mathrm{b.w}$. of atenolol for six months was found compared to the control activity. The administration of $0.26,0.52$ and $0.78 \mathrm{mg} / \mathrm{kg}$ b.w. of amlodipine for one, three and six months caused highly significant increases in the activities of ALP in the liver, spleen and kidney homogenates compared to the corresponding activities of the controls.

The results of RAPD-PCR for DNA samples isolated from liver, kidney and spleen of control mice and mice treated for 1, 3 and 6 months with various doses of captopril, atenolol or amlodipine are shown in [Fig-1a], [Fig-1b], [Fig-1c]. The amplification of products obtained by this technique showed the presence of numerous bands between 2 and $23 \mathrm{kbp}$ [Fig-1c]. The primer gave a recognizable profile of bands for amlodipine treated samples [Fig-1c] for 6 months compared to atenolol, captopril [Fig-1a] \& [Fig-1b] and control samples [Fig-1a], [Fig-1c]. Overall, the treatment by amlodipine caused more changes in RAPD-PCR patterns than treatment by either captopril or atenolol especially in liver, spleen and kidney.

\section{Discussion}

The hypertension increases the risk for stroke and coronary heart disease and is a main contributor to pre-mature death [20]. Toxic effects of drugs may be functional, biochemical, structural and specific. Such effects are evaluated by assessment of oxidantantioxidant parameters in tissues and severity of DNA damage [21]. The pathology of essential hypertension may involve one or more abnormalities in cardiovascular homoeostatic mechanisms including endothelial dysfunction [22]. The endothelial dysfunction is related to a defect in vasodilator nitric oxide (NO) synthesis. There may be an elevation of reactive oxygen species like superoxide anion, which inactivate the NO. Normally, the endogenous antioxidant mechanism involving enzymes like catalase and superoxide dismutase in addition to reduced glutathione scavenge and regulate the superoxide formed. This protective mechanism may be defective in essential hypertension cases [23]. In the present study the effects of treatment with the antihypertensive drugs amlodipine, atenolol and captopril on alkaline phosphatase (ALP) activity and genomic DNA was investigated in liver, spleen and kidney of mice. After chronic administration of captopril and amlodipine, the activity of ALP in liver, spleen and kidney homogenates were highly significantly increased compared to its level in the organs of the control mice. These finding are in accordance with those reported by Nishiya and Sugimoto [24], Gradosova, et al [25] and Moraes, et al [26]. Tonelli et al [27] reported that the higher level of ALP can be used as a marker for patients with an underlying inflammatory state, vas- cular calcification and as a liver function. Some investigators showed that the chronic administration of captopril affected the promotion of the secretion of ALP and its level depends on the dose of captopril [10]. The present results demonstrated that chronic administration of atenolol exhibited significant increase in the activity of ALP. These results are in good agreement with those of other investigators [28]. The elevation of ALP activity in normal mice after administration of antihypertensive drugs may reflect a link between the abnormal mineral metabolism of kidney and excess cardiovascular mortality [16, 29].

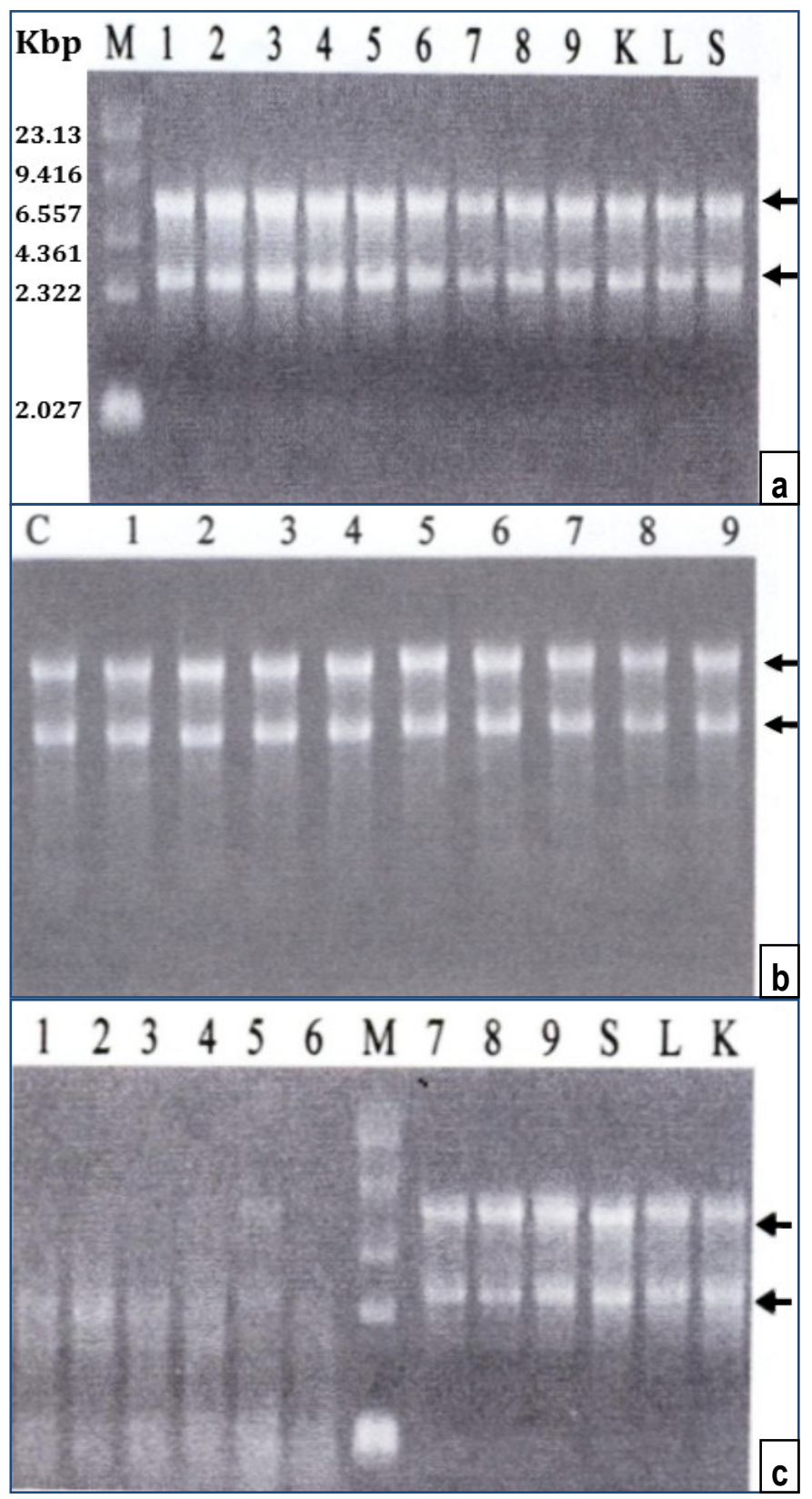

Fig. 1- RAPD- PCR analysis of DNA samples isolated from livers (lanes 1-3); spleen (lanes 4-6) and kidney (lanes 7-9) of captopriltreated (a); atenolol- treated (b) and amlodipine-treated mice (c) : Lane M :standard molecular weight marker Lanes K, L, S in Fig. 1a and $1 \mathrm{c}$ : kidney, liver and spleen DNA of control mice. Lane $\mathrm{C}$ in Fig.

$1 \mathrm{~b}$ : liver DNA of control mice. Lanes 1, 4, 7 : samples after one month treatment ; Lanes 2, 5, 8: samples after 3 month treatment; Lanes 3, 6, 9: samples after 6 month treatment 
The analysis of genomic alterations in liver, spleen and kidney of mice treated with atenolol and captopril using RAPD-PCR fingerprinting showed that these drugs did not produce significant changes in the RAPD-PCR fingerprints of the liver, spleen and kidney genomes. Both drugs produced nearly the same DNA banding patterns similar to that of control (non-treated) mice. However, amlodipine exerted an adverse affect on the DNA content of the liver, spleen and kidney. Apparently, amlodipine degraded the liver, spleen and kidney DNA and masked the sites for the annealing of the RAPD primers. These present finding are disagreeable with previous studies reporting that long term therapy of atenolol increased expression of fragile sites of DNA and caused chromosomal aberrations [30-31]. On the other hand, the present results are in consistent with the results of other investigators [32] who reported that atenolol and captopril did not show any significant antiproliferative effect on the cultured rat aortic smooth muscle cells throughout any of the studied doses. Many studies indicated that the calcium channel blocker amlodipine influences DNA and affect bone tissues resulting in decrease in bone resorption [33-35]. In these previous reports, accumulating data suggested that this calcium channel blocker (amlodipine) has antiinflammatory-antioxidant and antiapoptotic properties beside its antihypertensive action [36-37]. To summarize, our results clearly indicated that the chronic administration of amlodipine affected the genomic DNA and the activity of ALP. The present results may be attributed to: [1] the balance between inorganic pyrophosphate and serum phosphate which regulates vascular calcification. [2] imbalance in oxidant and antioxidant levels due to hypertension which resulted in accumulation of DNA damage with time [38]. In addition it is concluded that the studied antihypertensive drugs may induce inflammation by increasing the activity of ALP.

\section{References}

[1] Zhang X., Sun Z., Zheng L., Li Z., Liu S., Xu C. (2007) Archives of Medical Research, 38(4), 432-439.

[2] Vasdev S., Gill V.D., Singa P.K. (2006) Exp. Clin. Cardiol., 11 (3), 206-216.

[3] Lassegue B. and Griendling K.K. (2004) Am. J. Hypertens., 17, 852-860.

[4] Manning R.D., Jr. Tian N., Meng S. (2005) Am. J. Nephrol., 25, 311-317.

[5] Rao K.S. (2009) Indian Journal of Biochemistry and Biophysics, 46, 9-15.

[6] Perera S. and Bapat B. (2007) Atlas of Genetics and Cytogenetics in Oncology and Haematology.

[7] Shimizu H., Nakagami H. Osako M.K., Hanayama R., Kunugiza Y., Kizawa T. (2008) The Journal of Federation of American Societies for Experimental Biology, 22, 2465-2475.

[8] Liu L.L., Li Q.X., Xia L., Li J. (2007) Toxicology, 231, 8190.

[9] Devabhaktuni M. and Bangalore S. (2009) Vasc. Health Risk Manag., 5, 377-387.

[10]Liu Y.Y., Ya W.M., Wu T., Xu B.L., Chen F., Cui L. (2011) J. Bone Miner. Metab., 29(2), 149-58.

[11]Wadworth A.N., Murdoch D., Brogden R.N. (1991) Drugs, 42(3), 468- 510.

[12]Akif M., Georgiadis D., Mahajan A., Dive V., Sturrock E.D., Isaac R.E., Acharya K.R. (2010) Journal of Molecular Biology,
400(3), 502-517.

[13]Harmey D., Hessle L., Narisawa S., Johnson K.A., Terkeltaub R, Millan J.L. (2004) Am. J. Pathol., 164, 1199-1209.

[14]Schoppet M. and Shanahan C.M. (2008) Kidney Int., 73, 989991.

[15]Regidor D.L., Kovesdy C.P., Methrotra R., Rambod M., Jing J., McAllister C.J., van Wyck D. (2008) J. Am. Soc. Nephrol., 19, 2193-2203.

[16]Ali A.T., Penny C.B., Paiker J.E., Psaras G., Ikram F., Crowther N.J. (2006) Ann. Clin. Biochem., 43, 207-13.

[17]Lowry O.H., Rosebrough N.J. Farr A., Randall R.J. (1951) J. Biol. Chem., 193, 265-275.

[18]Williams J.G.K., Kubellik A.R., Livak K.J., Rafalski J.A, Tingy S.V. (1990) Nucleic Acid Research, 18(22), 6531-6535.

[19]Murry R.S. (1982) Schaum,s Outline Series of Theory and Problems of Probability and Statistics, McGraw-Hill Book Company, Singapore, 8, 265-298.

[20]Yadav S., Boddula R., Genitta G., Bhatia V., Bansal B. (2008) Indian J. Med. Res., 128, 712-720.

[21]Polat B., Suleyman H., Alp H.H. (2010) Chem. Biol. Interact., 186(1), 82-89.

[22]Beevers G., Lip G.Y.H., Brien E. (2001) British Medical Journal, $322,912-916$

[23]Touy R.M. (2004) Hypertension, 44, 248-252.

[24]Nishiya Y. and Sugimoto S. (2001) Biol. Pharm. Bull., 24(6), 628-33.

[25]Gradosova I., Zivna H. Svejkovska K., Palicka V., Tichy A., Zivny P. (2011) Acta. Vet. Brno, 80, 391-396.

[26]Moraes R.B., Correa L., Luz J.G. (2011) Oral Maxillofac. Sur., 15(2), 93-101.

[27]Tonelli M., Curhan G., Pfeffer M. Sacks F., Thadhani R. (2009) Circulation, 120, 1784- 1792

[28]Mota A., Silva P., Neves D., Lemos C., Calhau C. (2008) Braz. J. Med. Biol. Res., 41(7), 600-609.

[29]Blayney M.J., Pisoni R.L., Bragg-Gresham J.L., Bommer J., Piera L., Saito A. (2008) Kidney Int., 74, 655- 663.

[30]Telez M., Martinez B., Criado B., Lostao C.M., Penagarikano O., Ortega B. (2000) Mutagenesis, 15(3), 195-202.

[31]Telez M., Eduardo O.L., Gonzalezc, A.J., Floresd P. (2010) Mutation Research, 695, 46-54.

[32]Liu Y.Y., Cui L., Wu T. (2006) Chinese J. of Gerontology, 2.

[33]Rejnmark L., Vestergaard P., Mosekilde L. (2006) J. Hypertension, 24, 581-589.

[34]Ushijima K., Liu Y., Maekawa T., Ishikawa E., Motosugi Y., Ando H. (2010) Eur. J. Pharmacol., 635, 227-230.

[35]Subash P., Premagurumurth K., Sarasabharathi A., Cherian K.M. (2010) J. of Human Hypertension, 24, 475- 482.

[36]Yamagata K., Ichinose S., Tagami M. (2004) Hypertens. Res, 27, 271-282.

[37]Yoshii Y., Iwai M., Li Z. (2006) Hypertens. Res., 29, 457- 466.

[38]Khanna H.D., Sinha M.K., Khanna S., Tondon R. (2008) Indian J. Pharmacol., 52(3), 283-287. 